\title{
Development of hybrid photo-wind power systems with a diesel generator to overcome energy shortages
}

\author{
Faez Al-Rufaee ${ }^{1, *}$, LaythuAbd $\mathrm{Ali}^{2}$, and Vladimir Kuvshinov ${ }^{3}$ \\ ${ }^{1}$ Wasit University, 52000 Wasit, Iraq \\ ${ }^{2}$ University of Kufa, 54001 Najaf, Iraq \\ ${ }^{3}$ Sevastopol State University, Institute of Nuclear Energy and Industry, 299015 Sevastopol, Russia
}

\begin{abstract}
The paper discusses the possibilities of using hybrid composite structures to overcome the energy shortage in Iraq, as well as the development of an efficient system of solar, wind turbine diesel generators. In this article, a Diesel Generator is combined with a wind turbine and batteries on the basis that the sun's energy is not constant over time. The simulation was carried out using the HOMER program, which allows a detailed analysis of the volume and power of energy generated by the proposed system. The HOMER program is used for technical, economic, and environmental assessments. According to the results of the study, it was established that the most effective solution for saving electricity and overcoming energy shortages is a system consisting of renewable sources, as well as a diesel generator with batteries. The results also show that renewable energy sources used in the hybrid system provide about $69.2 \%$ of the electricity generated. This certainly improves the reliability of the electricity generated and reduces the fuel and maintenance costs of diesel generators, as well as saving the environment. The analysis of optimal systems is explained in detail to find the most achievable autonomous system.
\end{abstract}

\section{Introduction}

Regular supply of electricity is one of the most important requirements for the continuous normal functioning of industrial, commercial, household, and agricultural human activities [1]. Over time, the demand for electricity does not fall, but only continues to grow. That is why electric energy is considered one of the driving forces behind the growth of the economy of any state. At the same time, significantly increased consumer demand is putting serious pressure on the infrastructure of countries, forcing it to meet the increased demand. [1,2]. Much research has been done on the feasibility of using renewable energy technologies in Iraq. In [3], the authors studied a hybrid solar cell system and a diesel generator and found it suitable for on-site power generation. In [4], the authors analyzed the efficiency of a hybrid fuel cell - PV (photovoltaic) for the production of electricity in rural

\footnotetext{
*Corresponding author: fa99ez@mail.ru
} 
areas. As a result, the proposed system is able to provide electricity using the appropriate components with the proposed control. In [5], the authors assessed the efficiency of the PVwind hybrid energy system for providing electricity to a rural area in Iraq. They found that a hybrid power system can provide power to rural areas outside the power grid.

Iraq's energy sector continues to face a major challenge. [6] Recently, the gap between peak demand and peak energy production has widened, especially during the summer months. Figure 1 above shows the electricity generation and demand in Iraq between 2010 and 2018, as Iraq has seen a significant increase in electricity consumption and the corresponding generation of electricity from these power plants that cannot meet the growing electricity demand [7-9].

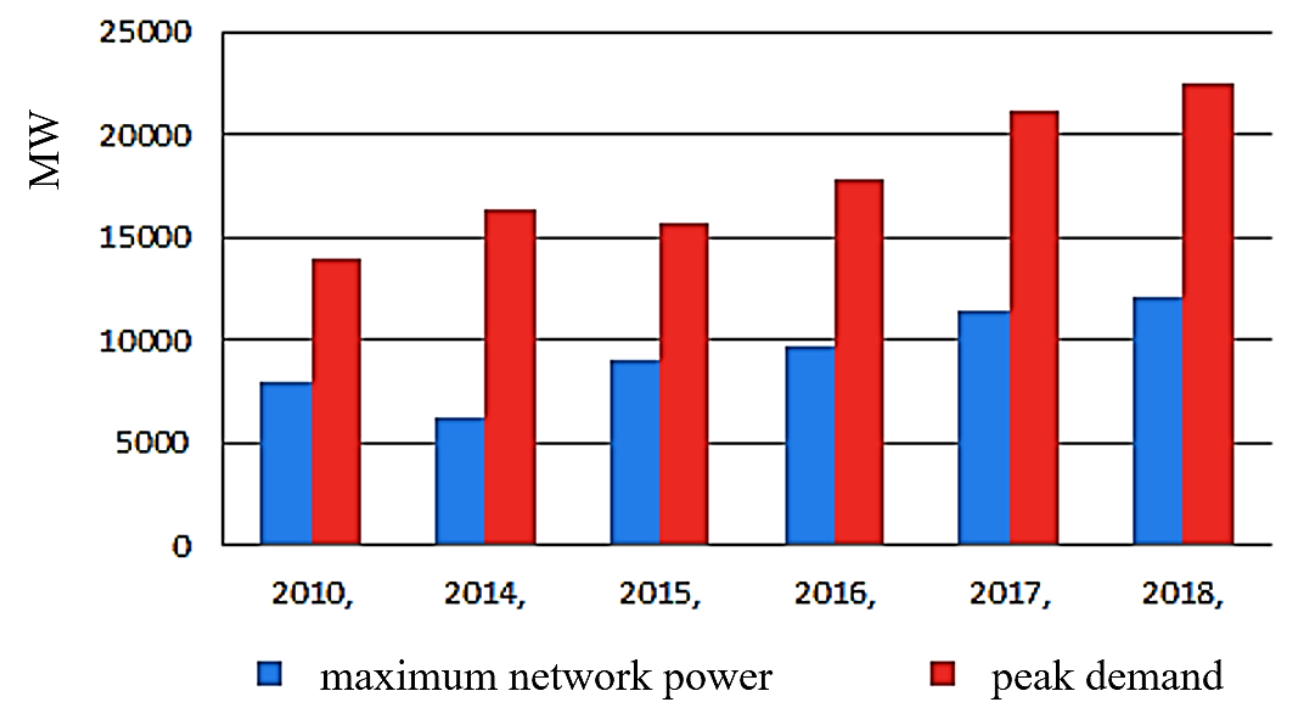

Fig. 1. Peak demand and maximum capacity from the grid, 2010-2018 [9]

Today, diesel generators are commonly used to generate electricity to overcome energy shortages. In recent years, prices for fuel and electricity production have shown significant growth. The problem of global climate warming also remains extremely urgent. The reason for its occurrence was a significant increase in the temperature of the planet's atmosphere, which occurred as a result of the constant burning of fossil fuels in huge quantities. A real alternative to clean energy can only be its renewable sources, such as wind and solar energy, etc. [2,10].

To reduce the consumption of fuel needed to generate electricity, some time ago, they began to use the energy of the sun, wind, etc. A hybrid photo-wind-diesel power system is capable of providing continuous energy generation [11, 12].

Purpose of work - The purpose of this paper is to consider the possibility of using hybrid composite structures to overcome the energy shortage in Iraq.

\section{Materials and methods}

Many regions of Iraq, as before, face difficulties in obtaining electricity, due to the lack of generated electricity. Iraq is located between latitudes $29^{\circ} 5^{\prime}$ and $37^{\circ} 22^{\prime}$ north latitude, and $38^{\circ} 45^{\prime}$ and $48^{\circ} 45^{\prime}$ east longitude The country is located in close proximity to the solar belt, which receives an average of 6-7 $\mathrm{kWh}$ of irradiation per square meter. Periods of solar activity: from 2500 to 3500 hours per year [13, 14]. Figure 2 shows the average annual temperature in the climatic conditions of Iraq. This feature allows the Iraqi government to 
solve the problem of electricity using renewable energy resources such as wind and solar energy [15].

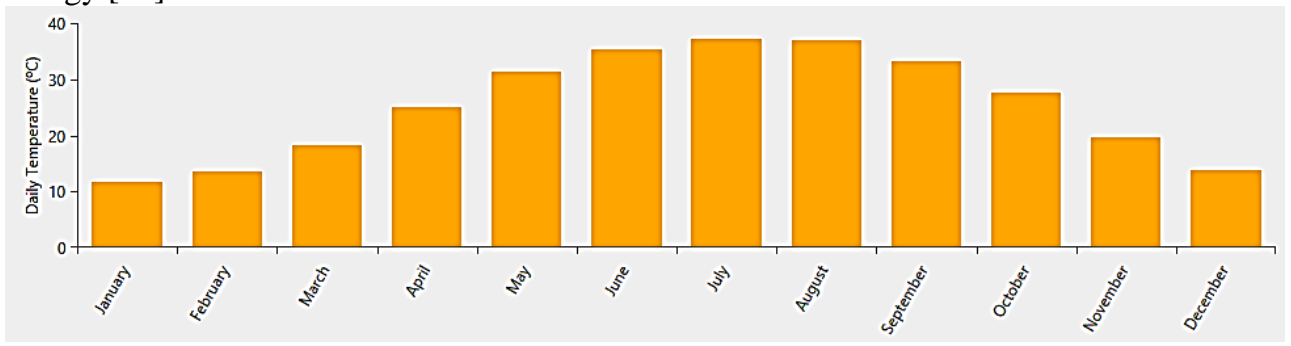

Fig. 2. Average annual temperature in the climatic conditions of Iraq.

A diesel generator, photovoltaic modules, a wind generator and batteries are included as a backup source in this study. Homer Software was used to simulate the proposed power generation system. HOMER is a program used for the analysis and design of hybrid energy systems, developed by the National Renewable Energy Laboratory (NREL), USA. Advantages of the HOMER program developed by NREL [16]:

- assists in the development of accurate energy systems;

- makes it easier to compare different methods of generating electricity;

- allows the designer to compare multiple design options based on technical and economic characteristics;

- $\quad$ simulates the operation of the system;

- calculates the energy balance for 8760 hours per year.

\subsection{Load profile data}

In remote rural areas, electricity is mainly used to illuminate buildings and streets and to ensure the uninterrupted operation of household equipment and mobile devices. The daily load identification file is shown in Fig. 4. The maximum demand for services is observed between 11.00 a.m. and 18.00 p.m. This situation is due to the fact that in rural areas, the main burden falls on the provision of cooling and lighting. The site load file by month is shown in Fig. 5.

Daily Profile

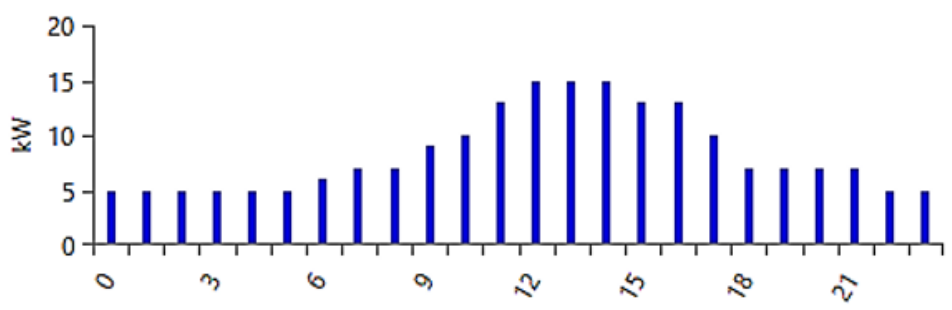

Fig. 4. Daily load profile 


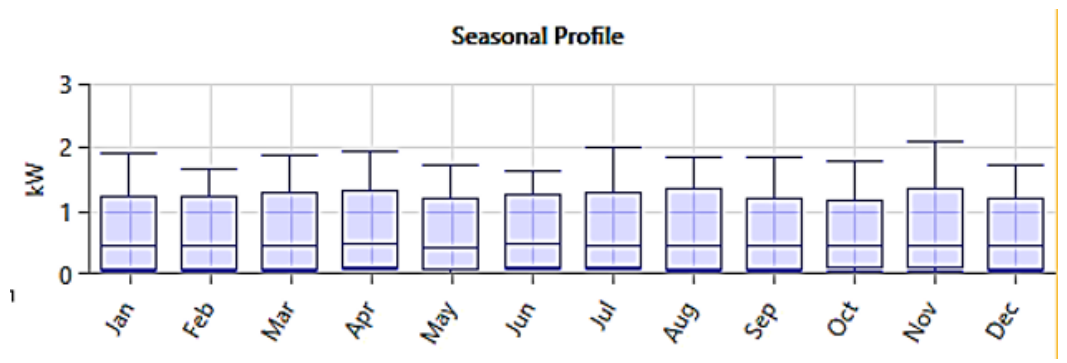

Fig. 5. Monthly load profile

\subsection{Photo-wind-diesel hybrid power system}

Hybrid systems are systems consisting of one or more renewable energy sources, for example, solar energy, wind energy, or others (diesel generators, etc.). The hybrid system ensures the generation and supply of high quality, clean electricity. In many cases, it is she who is considered more efficient in terms of material costs compared to single diesel systems. Therefore, the use of renewable energy sources is becoming an increasingly preferred solution for autonomous power generation [17, 18]. Parts of the system (wind turbine and solar panels) work according to the load requirements. If there is enough power, the excess power will fully charge the batteries. And if there is not enough energy due to low wind speed or solar radiation, diesel generators and batteries make up for the energy shortage.

In this study, the system refers to a hybrid system that combines photovoltaic panels, wind turbines and a diesel generator with a number of batteries Fig. 3. Photovoltaic panels provide higher reliability than individual cells because the power supply is not entirely dependent on any single source. For example, on a windy cloudy day, when electricity generation from photovoltaic power plants is low, wind turbines with a diesel generator are used to compensate for the loss of solar electricity [19].

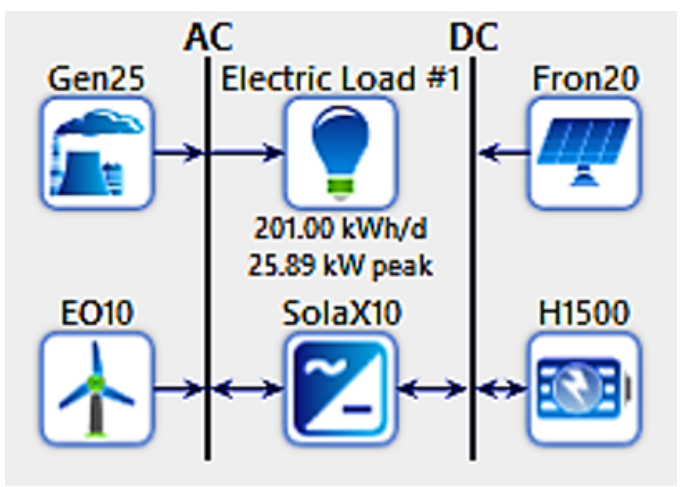

Fig. 3. Hybrid system design in the HOMER program

\subsection{Photovoltaic modules}

Solar energy is one of the most efficient means of generating electricity in places far from the national grid but characterized by an abundance of sunlight. Thus, solar energy is the main source of energy for the entire system. 
Photovoltaic systems are made up of modules. The latter also include several solar cells connected in series or in parallel to form a solar array.

Photovoltaic arrays are modeled by HOMER as devices that generate direct current electrical energy in proportion to their exposure to solar irradiation, regardless of temperature and voltage. In this analysis, SPV)Fron20) $20 \mathrm{~kW}$ were used. The equation shows the amount of energy generated by a photovoltaic system. [20]

$$
E_{p v}=A \times \eta_{m} \times P_{f} \times \eta_{p c} \times I
$$

where A is the area of photovoltaic modules $\left(\mathrm{m}^{2}\right)$,

$\eta_{m}$ - module efficiency $(0.111)$,

$P_{f}$ - packing factor $(0.9)$

$\eta_{p c}$ - efficiency of conditioning (0.86),

and I - irradiation $\left(\mathrm{kWh} / \mathrm{m}^{2}\right)$

Figure 6 shows monthly horizontal solar irradiance data for the proposed area.

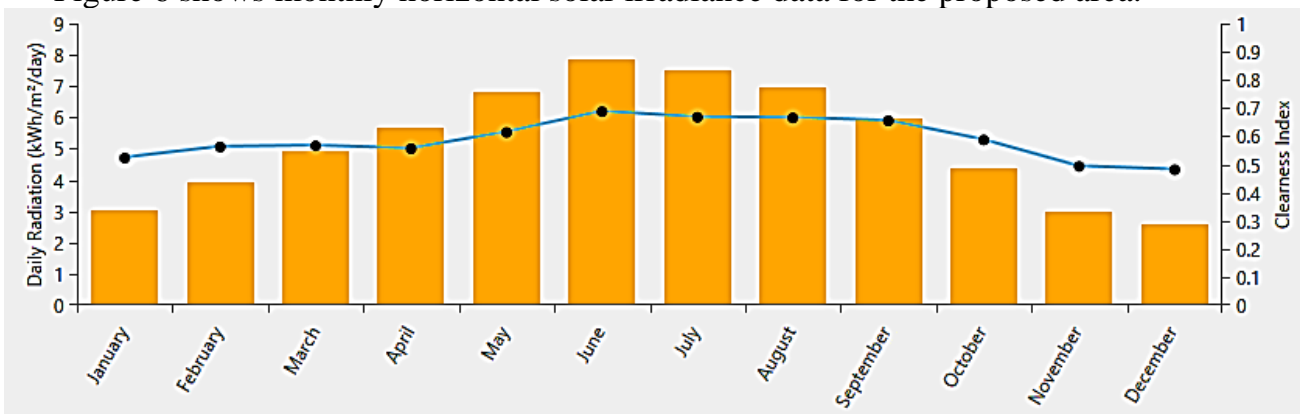

Fig. 6. Solar irradiation.

\subsection{Wind power}

The simulation uses a $10 \mathrm{~kW}$ (Eocycle EO 10) type wind turbine producing AC power. Figure 7 shows the average monthly wind speeds. The probability distribution of wind speed is calculated using mathematical expressions of the Weibull function, and the following formula is used to determine [21, 22]:

Where

$$
f(v)=\frac{k}{c} \times\left(\frac{v}{c}\right)^{k-1} \times \exp \left[-\left(\frac{v}{c}\right)^{k}\right]
$$

$k$ : Weibull shape parameter, (without units),

c: Weibull scale parameter, measured in $(\mathrm{m} / \mathrm{s})$,

$v$ : wind speed $(\mathrm{m} / \mathrm{s})$

The relationship between the average wind speed and Weibull parameters is described using the following formula [21]:

Where $\gamma$ is the gamma function.

$$
v_{\text {ave }}=c \times \gamma \times\left(\frac{1}{k}+1\right)
$$

The HOMER software uses the maximum likelihood method because it agrees well with the measured wind data.

Wind turbine power can be found by the formula [22]:

Where

$$
P_{\text {Вэу }}=\frac{1}{2} \cdot \rho \cdot \mathrm{A}_{\circ} \cdot \mathrm{C}_{\mathrm{p}} \cdot \vartheta_{\mathrm{p}}^{3}
$$


$\mathrm{P}_{w t p}$ : wind turbine power; $[\mathrm{kW}]$

$\rho$ : air density; $\left[\mathrm{kg} / \mathrm{m}^{3}\right]$

A0: wind wheel area; $\left[\mathrm{m}^{2}\right]$

$\vartheta$ P $\vartheta=0$ : design wind speed; $[\mathrm{m} / \mathrm{s}]$

$\mathrm{C}_{\mathrm{P}}$ : wind energy utilization rate.

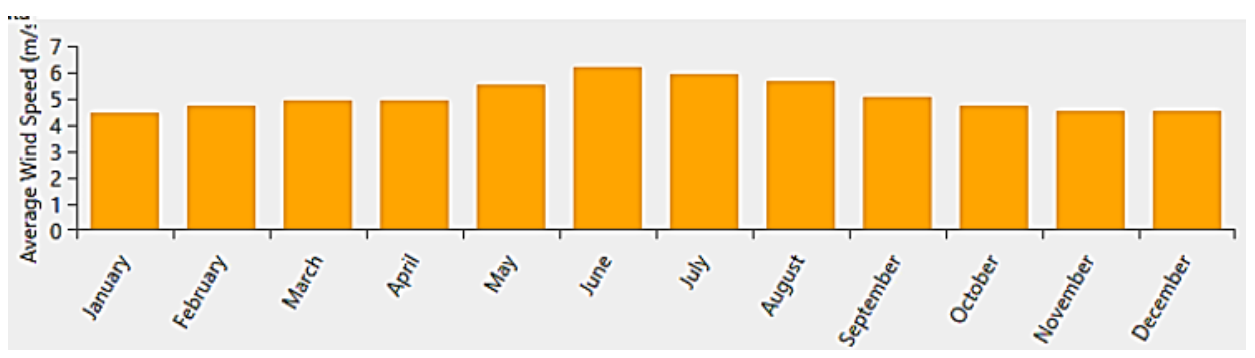

Fig. 7. Average monthly wind speed $(\mathrm{m} / \mathrm{s})$.

\subsection{Batteries}

Rechargeable batteries are used as backup equipment. The equipment should be used to maintain a constant voltage during peak periods or when generating capacity is not available. The program simulates a row of individual batteries to create an interconnected bank of batteries in a parallel row and determines whether the batteries will be charged or discharged per hour. Battery type suggested in the Hoppecke study 12 OPzS 1500 (H1500).

\subsection{Diesel generator}

The diesel generator proposed in the study can operate continuously to provide the required load. In addition, the size of the generator has been determined and will be upgraded in the future. The load does not exceed $80 \%$ of the generator's capacity to avoid overvoltage. The offered diesel generator has a power of $25 \mathrm{~kW}$ (Gen $25 \mathrm{~kW}$ ). The HOMER program decides how to start the generators every hour.

\subsection{Converter}

The converter is an electronic power device. This type of equipment is required in a system to maintain energy flow between AC and DC electrical components. The power of the converter used in this system is $10 \mathrm{~kW}$ (SolaX10).

\section{Results and discussion of results}

At HOMER, the process of simulating a small power system per hour is carried out on an annual basis. The proposed rural system operates on the basis of input factors (solar irradiation, wind speed, load, technical specifications) that are explained in advance.

In this study, the system contains a $20 \mathrm{~kW}$ SPVS, a $10 \mathrm{~kW}$ wind turbine, a $25 \mathrm{~kW}$ diesel generator, a $10 \mathrm{~kW}$ Converter and Batteries. The program simulates many components of the system to achieve the optimal composition of the system Fig. 8. Despite the fact that the program offers the most affordable option, we refused to analyze the current cost of the system. 


\begin{tabular}{|c|c|c|c|c|c|c|c|c|c|c|c|c|c|c|c|}
\hline \multicolumn{4}{|c|}{ Export... } & \multicolumn{3}{|c|}{ Export All... } & \multicolumn{8}{|c|}{$\begin{array}{l}\qquad \text { Sensitivity Cases } \\
\text { Left Click on a sensitivity case to see its Optimization Results. }\end{array}$} & Comp \\
\hline \multicolumn{12}{|c|}{ Architecture } & $\begin{array}{c}\text { Cost } \\
\mathrm{COE} \odot \nabla \\
(\$)\end{array}$ & \begin{tabular}{|c|} 
Gen25 \\
$\begin{array}{c}\text { Production } \\
(\mathrm{kWh})\end{array}$ \\
\end{tabular} & \begin{tabular}{|c|} 
Fron20 \\
$\begin{array}{c}\text { Production } \\
(\mathrm{kWh} / \mathrm{yr})\end{array}$ \\
\end{tabular} & $\begin{array}{c}\text { E010 } \\
\begin{array}{c}\text { Production } \\
(\mathrm{kWh} / \mathrm{yr})\end{array} \\
\end{array}$ \\
\hline$\triangle$ & 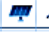 & 个 & 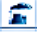 & 탕ㄱㄱ & Z & 20.0 & 20.0 & 1 & 25.0 & 16 & 10.0 & $\$ 0.306$ & 32,324 & 35,197 & 37,422 \\
\hline \multicolumn{12}{|c|}{ Architecture } & Cost & Gen25 & Fron20 & EO10 \\
\hline \multirow[t]{2}{*}{$\triangle$} & $m$ & 个 & in & 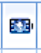 & Z & $\begin{array}{c}\text { Fron20 } \\
(\mathrm{kW})\end{array}$ & $\begin{array}{c}\text { Fron20-MPPT } \nabla \\
(\mathrm{kW})\end{array}$ & E010 $\nabla$ & $\begin{array}{c}\text { Gen25 } \nabla \\
(\mathrm{kW})\end{array}$ & H1500 マ & $\begin{array}{c}\text { SolaX10 } \\
(\mathrm{kW})\end{array}$ & $\underset{(\$)}{\mathrm{COE}} \odot \mathrm{P}$ & $\begin{array}{c}\text { Production } \\
(\mathrm{kWh})\end{array}$ & $\begin{array}{c}\text { Production } \\
(\mathrm{kWh} / \mathrm{yr})\end{array}$ & $\begin{array}{c}\text { Production } \nabla \\
(\mathrm{kWh} / \mathrm{yr})\end{array}$ \\
\hline & $\boldsymbol{4}$ & + & - & E㴗 & $\boldsymbol{z}$ & 20.0 & 20.0 & 1 & 25.0 & 16 & 10.0 & $\$ 0.306$ & 32,324 & 35,197 & 37,422 \\
\hline$\triangle$ & & t & in & 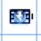 & z & & & 1 & 25.0 & 3 & 10.0 & $\$ 0.374$ & 59,603 & & 37,422 \\
\hline \multirow[t]{2}{*}{$\Delta$} & 4 & t & $\vec{n}$ & & z & 20.0 & 20.0 & 1 & 25.0 & & 10.0 & $\$ 0.437$ & 55,124 & 35,197 & 37,422 \\
\hline & 4 & & in & EX: & z & 20.0 & 20.0 & & 25.0 & 15 & 10.0 & $\$ 0.440$ & 55,211 & 35,197 & \\
\hline$\Delta$ & 4 & & $\vec{n}$ & & $\approx$ & 20.0 & 20.0 & & 25.0 & & 10.0 & $\$ 0.459$ & 61,486 & 35,197 & \\
\hline
\end{tabular}

Fig. 8. Simulation result of the HOMER program

Based on the simulation results, we note the following. The $0 \%$ electricity shortage indicates that the proposed system is suitable for providing $100 \%$ of the required electrical load and does not allow any electricity shortages throughout the year.

Figures 9,10,11 show the possibilities of generating energy from solar cells, wind turbines, and diesel generators in different months of the year. Table 1 shows the annual contribution of various energy sources to the proposed system.

Table 1. Annual energy production of the proposed hybrid system. Energy contribution of various energy sources.

\begin{tabular}{|c|c|c|c|c|c|c|}
\hline \multirow[b]{2}{*}{ production } & \multicolumn{2}{|c|}{$\begin{array}{c}1 \\
\text { Fron20-EO10- } \\
\text { Gen25 }\end{array}$} & \multicolumn{2}{|c|}{$\begin{array}{c}2 \\
\text { EO10-Gen25 }\end{array}$} & \multicolumn{2}{|c|}{$\begin{array}{c}3 \\
\text { Fron20-Gen25 }\end{array}$} \\
\hline & $\begin{array}{c}\mathrm{kWh} / \mathrm{y} \\
\text { ear }\end{array}$ & $\%$ & $\begin{array}{c}\mathrm{kWh} / \mathrm{y} \\
\text { ear }\end{array}$ & $\%$ & $\begin{array}{c}\mathrm{kWh} / \mathrm{y} \\
\text { ear }\end{array}$ & $\%$ \\
\hline $\begin{array}{c}\text { Photovoltaic } \\
\text { modules }\end{array}$ & 35,197 & 33.5 & - & - & 35,197 & 38.9 \\
\hline Diesel generator & 32,324 & 30.8 & 59,603 & 61.4 & 55,211 & 61.1 \\
\hline wind turbine & 37,422 & 35.7 & 37,422 & 38.6 & - & - \\
\hline Total & $\begin{array}{c}104,94 \\
2\end{array}$ & 100 & 97,025 & 100 & 90,408 & 100 \\
\hline Basic load & & & 73,365 & h/year & & \\
\hline Excess electricity & 31,577 & 29.4 & 23,662 & 24.4 & 16,231 & 18 \\
\hline
\end{tabular}

\section{Monthly Average Electric Production}

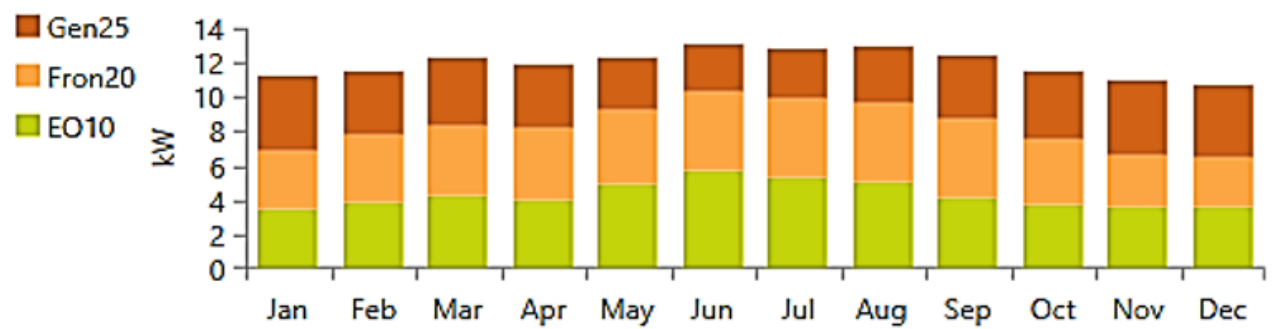


Fig. 9. Average monthly power generation photo-wind-diesel system.

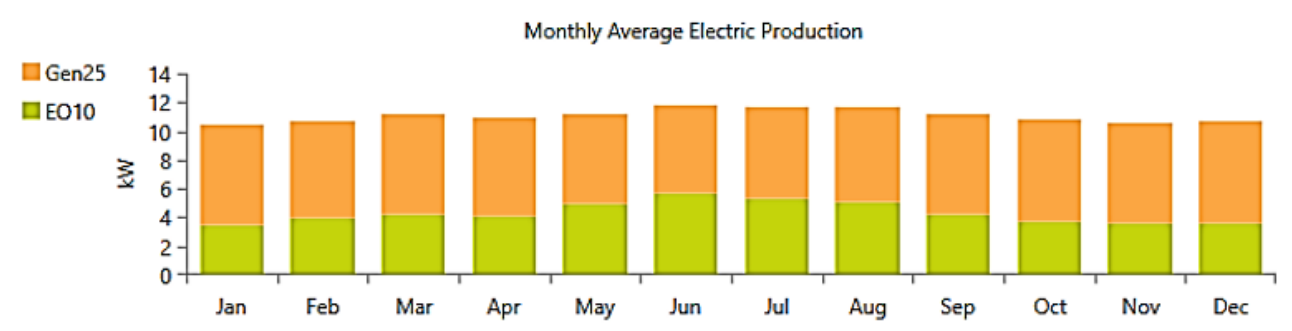

Fig. 10. Average monthly power generation wind-diesel system.

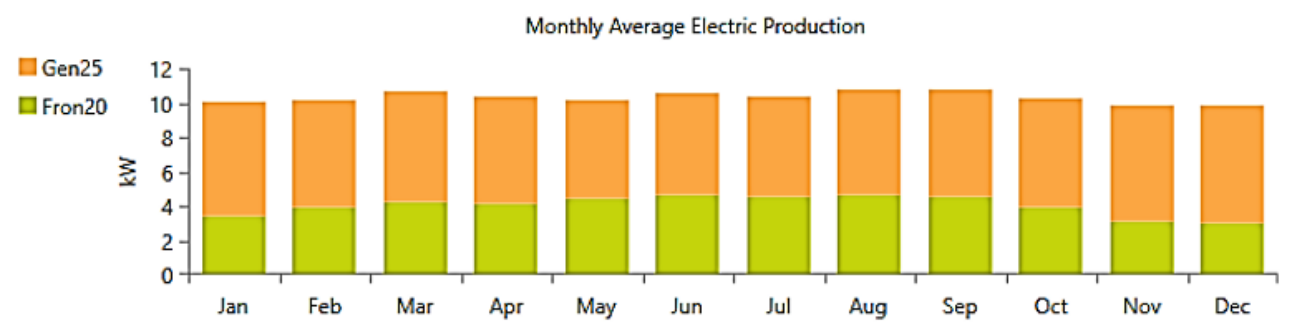

Fig. 11. Average monthly power generation photo-diesel system.

Based on the results obtained in Figures 9, 10, 11 and Table 1, it is seen that the production of electricity in three cases. First, when the system consists of a photo-wind-diesel generator. As a result, the system produces a surplus of energy by $29.4 \%$, and the share of renewable energy sources is $69.2 \%$. In the second case, the system consists of a wind turbine and a diesel generator, as a result, the System produces $24.4 \%$ of the surplus electricity and $38.6 \%$ of the participation of renewable resources. The third case of the system (solar panels and diesel generator). As a result, the system produces a surplus of energy of $18 \%$, and the participation of renewable resources is about $38.9 \%$. The findings suggest that renewable energy sources can play an important role in generating electricity in rural areas isolated from the grid, or to overcome energy shortages in various regions, especially solar and wind power, since a hybrid system of photo-wind-diesel generators produces excess electricity and reduces fuel consumption and emissions.

\section{Conclusion}

The study considered a solar and diesel generator power system as optimal, most efficient, and fully satisfying the demand for electrical loading in many parts of Iraq with solar and wind power available. Simulations were carried out using HOMER and using data on solar irradiation and wind speed provided by the program, load demand, and technical specifications. Thanks to the positive results obtained, it is possible to provide a large number of solutions that will become a good alternative to modern systems. Any of them can be used for the self-generation of energy, so that there is always enough electricity, regardless of the availability of the network. The system discussed in our study helps to reduce fuel consumption while conserving energy supply to the home. In addition, the results show that renewable energy sources, used in the hybrid system provide about $69.2 \%$ of the electricity generated. This certainly improves the reliability of the electricity generated and reduces the fuel and maintenance costs of diesel generators, as well as saving the environment. 
The authors would like to thank our colleagues at the Wasit University and the Sevastopol state university, for their invaluable support.

\section{References}

1. D.P. Kaundinya, P. Balachandra, N.H. Ravindranath, Renewable and Sustainable Energy Reviews, 13, 2041 (2009)

2. B.V. Lukutin, I.O. Muravlev, I.A. Plotnikov, Sistemy elektrosnabzheniya s vetrovymi $i$ solnechnymi elektrostanciyami, uchebnoe posobie, 128 (Tomsk: Izd-vo Tomskogo politekhnicheskogo universiteta, 2015)

3. A. S. Aziz, S. A. Khudhier, Am J Appl Sci, 14(1), 157 (2017)

4. Z. Nawawi, A. S. Aziz, Z. Buntat, M. A. B. Sidik, H. J. Kareem, A. Z. Abdulameer, M. A. A. Aziz, M. I. Jambak, Y.Z. Arief, Telkomnika, 14, 411 (2016)

5. Salwan S. Dihrab, K. Sopian, Renewable Energy, 35, 1303 (2010)

6. F. M. Al'-Rufai, L. M. Abdali, V. V. Kuvshinov, Energeticheskie ustanovki i tekhnologii, 5(2), 74 (2019)

7. Ministry of Electricity of Iraq: Components of the electrical system.I

8. F. M. Al'-Rufai, L. M. Abdali, V. V. Kuvshinov, B. A. YAkimovich, Vestnik IzhGTU imeni M. T. Kalashnikova, 3(3), 105 (2020)

9. Ministry of Electricity of Iraq: Components of the electrical system

10. Harry H. Istepanian, Solar Energy in Iraq: From Outset to Offset, Iraq Energy Institute, 25 (2018)

11. L. M. Abdali, F. M. Al'-Rufai, B. A. YAkimovich, V. V. Kuvshinov, Vestnik IzhGTU imeni M. T. Kalashnikova, 23(2), 100 (2020)

12. P. N. Kuznecov, V. V. CHeboksarov, B. A. YAkimovich, Vestnik IzhGTU imeni M. T. Kalashnikova, 23(1), 45 (2020)

13. V.V. Guryev, B.A. Yakimovich, F.M. Al-Rufaee, Appl. Sol. Energy, 55(3), 189 (2019)

14. Hussain H. Al-Kayiem, T. Sanan, Resources, 8, 42 (2019)

15. V.V. Kuvshinov, F.M. Al-Rufaee, Appl. Sol. Energy, 55(4), 252 (2019)

16. HOMER Energy, http:www.homerenergy.com

17. L.M. Abd Ali, F.M. Al-Rufaee, V.V. Kuvshinov et al., Appl. Sol. Energy, 56, 284 (2020)

18. H. Ahmed Mohmmed, M.O.H. Anssari, L.M. Abdali, J. Eng. Appl. Sci., 14, 4414 (2019)

19. M.R. Patel, Wind and Solar Power Systems: Design, Analysis, and Operation, 2nd Ed, (Boca Raton: Taylor \& Francis Group, 2006)

20. K. Kusakana, H. J. Vermaak, International Conference on Clean Electrical Power (ICCEP), 703 (2011)

21. A. S. Aziz, Turk J Elec Eng \& Comp Sci, 25, 2122 (2017)

22. S. Ishaq, S. Naveed, S. M. Khan, M. Najam-ul-Islam, Int J Renew Energy Res, 6(4), 1318 (2016)

23. V. V. Kuvshinov, N. V. Morozova, I. YU. Sofijskij, Vozmozhnosti ispol'zovaniya energeticheskih ustanovok na osnove vozobnovlyaemyh istochnikov energii, 290 (Sputnik +, 2017) 